\title{
Comparison of free lipid compositions between roots and leaves of plants in the Dajiuhu Peatland, central China
}

\author{
Xianyu Huang, ${ }^{1}$ Canfa Wang, ${ }^{2}$ JinXIAng Zhang, ${ }^{1}$ Guido L. B. Wiesenberg, ${ }^{3}$ \\ ZHIQI ZHANG ${ }^{4}$ and SHUCHENG XIE ${ }^{2 *}$ \\ ${ }^{1}$ State Key Laboratory of Geological Processes and Mineral Resources, China University of Geosciences, Wuhan 430074, China \\ ${ }^{2}$ Key Laboratory of Biogeology and Environmental Geology, Ministry of Education, China University of Geosciences, \\ Wuhan 430074, China \\ ${ }^{3}$ Department of Agroecosystem Research, University of Bayreuth, Bayreuth 95440, Germany \\ ${ }^{4}$ Administration of Dajiuhu National Wetland Park of Shennongjia, Shennongjia 442417, China
}

(Received November 16, 2010; Accepted April 30, 2011)

\begin{abstract}
The main aim of this study was to assess the free lipid composition of plant community in a Chinese peatland. Twelve plant species from the Dajiuhu Peatland were analyzed for the compositions of $n$-alkanes, $n$-fatty alcohols and sterols in leaves and roots. The lipid compositions are significantly different between root and leaf for most plants. In some cases, the roots yield more long chain $n$-alkanes and $n$-alkanols than the leaves of the corresponding plant. The long chain $n$ alkanes of the roots in half of the plant species are characterized by a higher $C_{\max }$ (homologue with the maximum concentration) relative to the leaves. The root-derived sterols and steroidal ketones may be important sources for corresponding compounds within the peat. Because of the different lipid compositions of roots and leaves, more attention should be paid to root-derived lipids for investigations of the lipid composition and their source assessment in soils and terrestrial sediments, where root-derived organic matter can be an important source. The contribution of root-derived lipids may be especially important in peatlands, where acidic and/or anoxic conditions in the subsoil limit the degradation of organic matter and the contribution of leaf litter.
\end{abstract}

Keywords: plant roots, $n$-alkanes, $n$-alkanols, peatland, steroidal ketones

\section{INTRODUCTION}

The free and bound lipids ( $n$-alkanes, $n$-fatty alcohols and steroids) contribute a great part of organic matter preserved in soils and sediments, and these can be used as biomarkers for their source plants and the associated environmental conditions (e.g., Rieley et al., 1991; Meyers and Ishiwatari, 1993; Schwark et al., 2002; Xie et al., 2004; Wiesenberg and Schwark, 2006; Huang et $a l ., 2008)$. To effectively interpret the origin of the lipids in soils and sediments, it is crucial to investigate how and where lipids are distributed in modern plants. However, most studies have focused on leaf waxes (e.g., Rieley et al., 1991; Ficken et al., 1998, 2000; Schwark et al., 2002; Bi et al., 2005; Jansen et al., 2006; Rommerskirchen et al., 2006; Cui et al., 2008; Grice et al., 2008; Huang et al., 2011). There have been fewer reports of root-derived lipids and their significance for sedimentary organic matter (Otto et al., 1994; Pancost et al., 2002; Wiesenberg et

*Corresponding author (e-mail: xiecug@163.com)

Copyright $(2) 2011$ by The Geochemical Society of Japan. al., 2004, 2010; Jansen et al., 2006; Kuhn et al., 2010; Mendez-Millan et al., 2010). In order to acclimatize to the specific conditions of peatlands (waterlogged, nutrient poor and partly anoxic and acidic), plants develop shallow but flourishing root systems (Rydin and Jeglum, 2006), which can contribute high amount of lipids to peat deposits. To date, only Pancost et al. (2002) noted the root-derived lipids from peat-forming plants.

A number of studies have reported the lipid compositions of peatland plant communities (Ficken et al., 1998; Nott et al., 2000; Pancost et al., 2002; Nichols et al., 2006). These communities were distributed in Europe and North America, while the results in other regions were not available in the literature to the best of our knowledge. In addition, except for the peat moss (Sphagnum species) shrubs are abundant in the above bogs. In contrast, the Dajiuhu Peatland is characterized by Sphagnum palustre and various herbaceous plants. It is, therefore, worth assessing the lipid composition of the plant community in such an herb peatland. The $n$-alkane distributions of several moss species (S. palustre, Aulacomnium palustre, Polytrichum commune and Hypnum revolutum) from the area have been previously reported by Huang $e t$ al. (2010). 
In this study, we compared the free lipid distributions in roots and leaves of plant species collected from the Dajiuhu Peatland. The aim of this study was to evaluate the composition of root lipids relative to leaf lipids in the plant community of this peatland in central China.

\section{Materials AND Methods}

Sampling

The Dajiuhu Peatland in Shenongjia Forestry Region, Hubei Province, China, has developed in a sub-alpine closed basin (over $1700 \mathrm{~m}$ above sea level) and extends over an area of about $16 \mathrm{~km}^{2}$. The peat sediments reach a thickness of more than $2 \mathrm{~m}$. The $\mathrm{pH}$ of the modern surficial peat is $c a .4-5$, and the water table is normally $10-50 \mathrm{~cm}$ below the surficial horizons (Huang et al., 2010). The local climate is dominated by the East Asian monsoon, with a mean annual rainfall of $1560 \mathrm{~mm}$ and a mean temperature of $7.2^{\circ} \mathrm{C}$. Within the peatland, Sphagnum palustre is the dominant cover plant, together with herbaceous plants such as Carex spp., Juncus effusus and Euphorbia esula.

The twelve most abundant plant species were collected for root and leaf lipid analysis from the Dajiuhu Peatland in June, 2009. For the samples to be representative, over ten individual plants were collected for each species. All the plants are herbs except the fern Dryopteris sp.

\section{Extraction and fractionation}

Plant samples were carefully washed with deionized water, divided into roots and leaves, and then cut into small pieces using scissors. The leaf and root parts were immersed in dichloromethane (DCM) for $1 \mathrm{~min}$ to extract the epicuticular wax (Jetter et al., 2006). The $n$ eicosane- $\mathrm{d}_{42}, n$-tetracosane- $\mathrm{d}_{50}$, and $n$-triacontane- $\mathrm{d}_{62}$ (Chiron, Norway) were added as internal standards before the extraction. The extracts were fractionated into aliphatic (including $n$-alkanes), polar-1 (including $n$ alkanols and sterols) and polar-2 fractions using silica column chromatography, with hexane, DCM and methanol $(1: 1, v / v)$, and methanol as eluting solvents, respectively.

\section{$G C$ and $G C-M S$ analyses}

Polar-1 fractions, after silylation using bis(trifluoroacetyl)-trifluoroacetamide (BSTFA), were analyzed using gas chromatography-mass spectrometry (GC-MS) with a Hewlett Packard 6890 gas chromatograph coupled to a Hewlett Packard 5973 mass selective detector. The oven temperature was ramped from $70^{\circ} \mathrm{C}$ (held 1 min) to $210^{\circ} \mathrm{C}$ at $10^{\circ} \mathrm{C} \mathrm{min}^{-1}$ and then to $300^{\circ} \mathrm{C}$ (held 20 $\min )$ at $2^{\circ} \mathrm{C} \mathrm{min}^{-1}$. Individual components were identified using a combination of $\mathrm{GC}$ relative retention times of standards and published mass spectra (Djerassi, 1978;

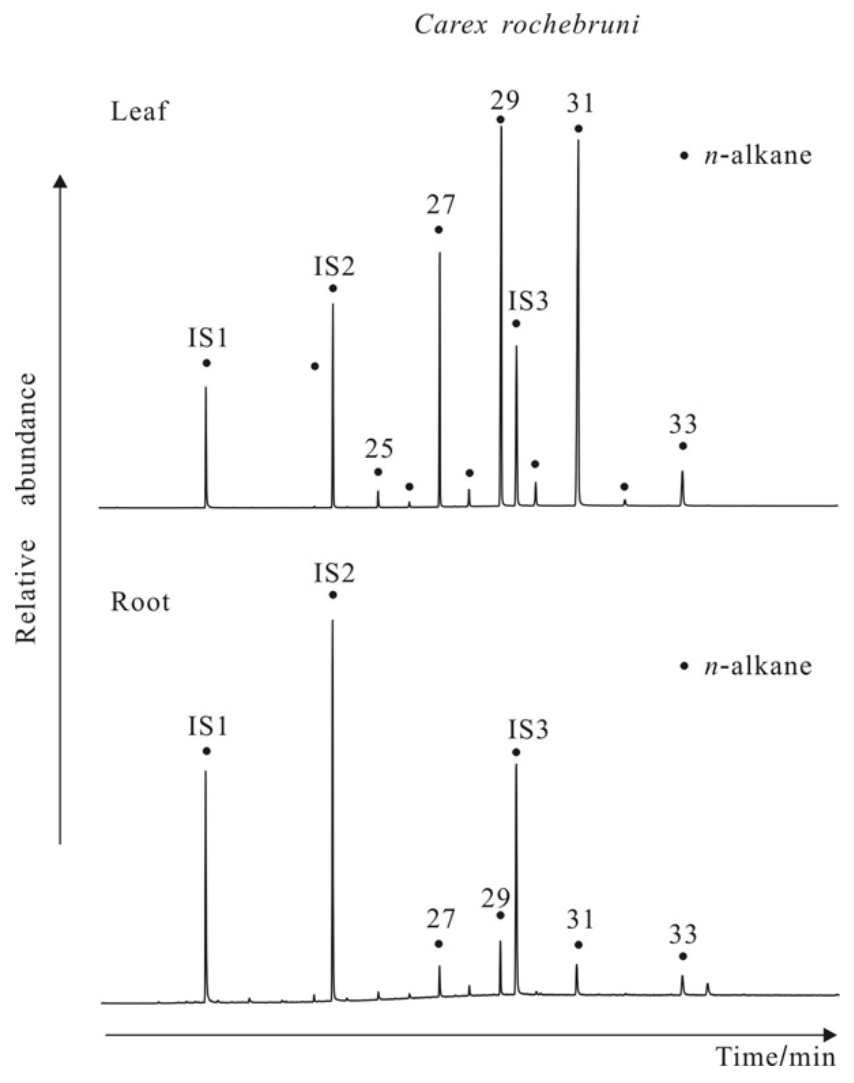

Fig. 1. The total ion chromatograph (TIC) of aliphatic fraction of Carex rochebruni.

Gagosian et al., 1982; Duan and Ma, 2001). The $\mathrm{C}_{29}$ sterones were tentatively identified as follows: stigmasta3,5-dien-7-one, characterized by prominent $\mathrm{m} / \mathrm{z} 174$ from C-ring cleavage and stigmast-4-en-3-one, with a characteristic ion at $\mathrm{m} / \mathrm{z} 124$ from B-ring cleavage. The root/ leaf ratios of $n$-alkanols, sterols and stenones were calculated based on the characteristic ions $(\mathrm{m} / \mathrm{z}$ 103, 129 and 124/174, respectively).

The abundances of long chain $n$-alkanes were measured using a Shimadzu GC 2010 equipped with a flame ionization detector (FID). The oven temperature was ramped from $70^{\circ} \mathrm{C}$ (held $1 \mathrm{~min}$ ) to $210^{\circ} \mathrm{C}$ at $10^{\circ} \mathrm{C} \mathrm{min}{ }^{-1}$ and then to $300^{\circ} \mathrm{C}$ (held $25 \mathrm{~min}$ ) at $3^{\circ} \mathrm{C} \mathrm{min}^{-1}$. Components were identified by comparison with the retention times of $n$-alkane standards (Supelco, USA). The absolute abundances were calculated by comparison of peak areas with those of known quantities of standards and adjusted with the relevant FID response factors.

\section{RESULTS AND DISCUSSION}

n-Alkanes

The aliphatic fractions of all the samples are domi- 


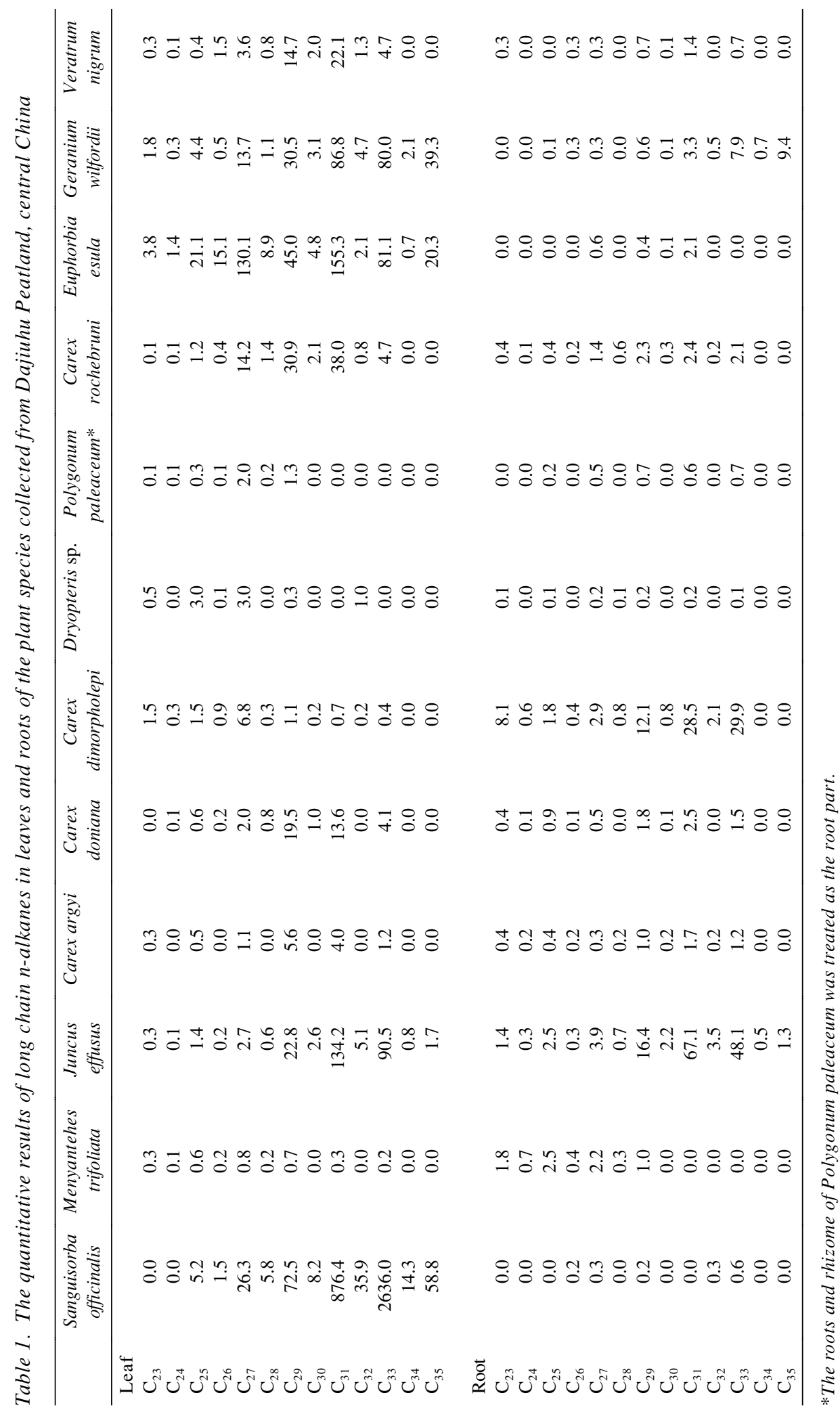



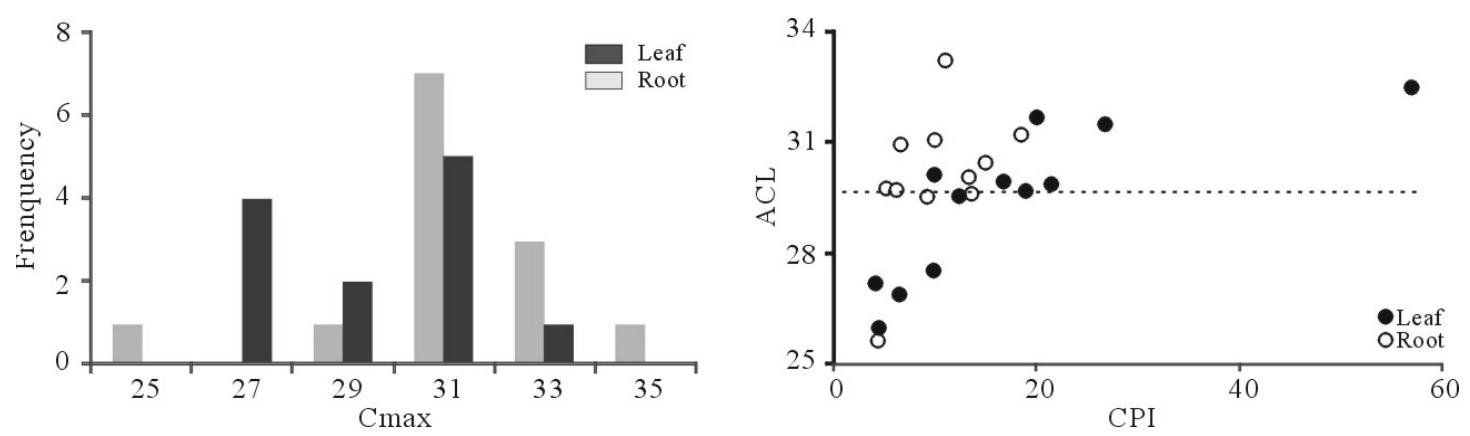

Fig. 2. (a) Frequency of $C_{\max }$ of long chain n-alkanes in the roots and leaves of plant species from the Dajiuhu Peatland. In the example (root of $C$. rochebruni) where the pattern has two dominant homologues, both are treated as $C_{\text {max }}$ (b) Plot of ACL against CPI of n-alkanes. Dashed horizontal line refers to mean value of ACL of all plant samples (29.7).

$$
\begin{aligned}
& A C L=\sum_{i}^{n}\left(C_{i} \times i\right) / \sum_{i}^{n} C_{i}(i=23-35, \text { odd }) . \\
& C P I=\frac{\left(C_{23}+C_{25}+C_{27}+C_{29}+C_{31}+C_{33}\right)+\left(C_{25}+C_{27}+C_{29}+C_{31}+C_{33}+C_{35}\right)}{2\left(C_{24}+C_{26}+C_{28}+C_{30}+C_{32}+C_{34}\right)} .
\end{aligned}
$$

Table 2. Plant species, type and root/leaf ratio of lipid contents normalized to 1 g biomass

\begin{tabular}{lcccrr}
\hline Species & Type & $n$-Alkane & $n$-Alcohol & Sterol & Stenone \\
\hline Sanguisorba officinalis & Herb & 0.00 & 0.00 & 3.09 & 9.45 \\
Menyantehes trifoliata & Herb & 2.93 & 0.43 & 4.88 & \\
Juncus effusus & Herb & 0.57 & 2.61 & 146.65 & 8.92 \\
Carex argyi & Herb & 0.30 & 0.21 & 21.92 & 95.27 \\
Carex doniana & Herb & 0.10 & 0.28 & 9.53 & 128.76 \\
Carex dimorpholepis & Herb & 6.72 & 13.94 & 16.84 & 7.10 \\
Carex rochebruni & Herb & 0.11 & 41.88 & 222.69 & 23.86 \\
Dryopteris sp. & Fern & 0.07 & 0.01 & 1.99 & 45.10 \\
Polygonum paleaceum & Herb & 0.59 & 0.10 & 10.56 & 385.29 \\
Euphorbia esula & Herb & 0.01 & 1.53 & 27.94 & 41.62 \\
Geranium wilfordii & Herb & 0.09 & 1.92 & 242.47 & 348.46 \\
Veratrum nigrum & Herb & 0.08 & 0.42 & 7.10 & 1.37 \\
\hline
\end{tabular}

nated by long chain $n$-alkanes $\left(\mathrm{C}_{21}-\mathrm{C}_{35}\right.$; Fig. 1 , Table 1$)$. All the patterns of carbon distribution show an obvious odd/even predominance, with carbon preference index (CPI, see Fig. 2 for formula) values ranging from 4.5 to 57.2 (avg. 14.1; Fig. 2b). These CPI signatures are similar with the previous results of leaf cuticle waxes (e.g., Rieley et al., 1991; Ficken et al., 2000; Cui et al., 2008).

The concentrations of the $n$-alkanes in the leaves vary greatly, ranging from less than 1 to over $2500 \mu \mathrm{g} / \mathrm{g}$. Sanguisorba officinalis, J. effuses and E. esula contain relatively high amounts of $n$-alkanes $(>100 \mu \mathrm{g} / \mathrm{g})$. The $C_{\max }$ of these species maximizes at a concentration of $>100 \mu \mathrm{g} / \mathrm{g}$ (relative to dry wt; Table 1). The leaves of five other species including Menyantehes trifoliata, Carex argyi, Carex dimorpholepis, Dryopteris sp. and Polygonum paleaceum contain relatively low amounts of $n$-alkanes, with a concentration of each compound being $<10 \mu \mathrm{g} / \mathrm{g}$ (Table 1).

The roots generally have quite low amounts (normally $<10 \mu \mathrm{g} / \mathrm{g}$ ) of long chain $n$-alkanes (Table 1 ). Only the roots of $J$. effusus and $C$. dimorpholepis show comparatively high concentrations of the dominant long chain $n$ alkanes (>10 $\mu \mathrm{g} / \mathrm{g}$; Table 1$)$.

For all the Dajiuhu plant species, the leaves generally contain significantly more $n$-alkanes than the roots (Table 2). For example, the concentrations of the $n$-alkanes in $S$. officinalis leaves are ca. 100 times as high as those in the roots (Table 2). E. tetralix and C. vulgaris in Pancost 
et al. (2002) also showed an enrichment of the $n$-alkanes in leaves compared to roots. However, the roots of $M$. trifoliata and $C$. dimorpholepis contained more long chain $n$-alkanes than their leaves (Table 2).

The Dajiuhu plant roots are generally dominated by $\mathrm{C}_{31}$ and $\mathrm{C}_{33}$-alkanes (Fig. 2a). The roots of both $E$. tetralix and $C$. vulgaris in a Dutch ombrotrophic bog were also dominated by $\mathrm{C}_{31}$ and $\mathrm{C}_{33}$ (Pancost et al., 2002). An exception exists in $M$. trifoliata roots, which possesses a relatively lower $C_{\max }\left(\mathrm{C}_{25}\right)$ that is similar to those of emersed/floating plants (Ficken et al., 2000) and Sphagnum fuscum (Ficken et al., 1998; Vonk and Gustafsson, 2009; Bingham et al., 2010). The $\mathrm{C}_{31}$ homologue is also the dominant $C_{\max }$ in most of the Dajiuhu plant leaves. However, in four of the twelve plants $(C$. dimorpholepis, M. trifoliata, P. paleaceum and Dryopteris sp.), $\mathrm{C}_{27}$ alkane is dominant (Fig. 2a).

Five of the twelve plant species ( $S$. officinalis, $J$. effusus, Carex rochebruni, E. esula and Veratrum nigrum) show identical $C_{\max }$ for roots and leaves. $M$. trifoliata contains higher $C_{\max }$ in the leaves (Table 1). The other six species (C. argyi, Carex doniana, $C$. dimorpholepis, Dryopteris sp., P. paleaceum and G. wilfordii), however, have a higher $C_{\max }$ in the roots than in the corresponding leaves. These differences in distribution patterns between roots and leaves are also clearly revealed by the values of average chain length (ACL; Fig. 2b). Eight of the twelve roots show a higher ACL value than the mean value of all plant samples (29.7).

The distributions of long chain $n$-alkanes also show variations within species of the same genera. Both the content and distribution patterns of the $n$-alkanes vary among the four Carex species (Table 1). The concentration of the $C_{\max }$ in $C$. doniana and $C$. rochebruni leaves is one order of magnitude higher than that in the leaves of $C$. argyi and $C$. dimorpholepis. In contrast, the roots of $C$. dimorpholepis contain a relatively higher amount of $n$-alkanes than the other three species. Furthermore, the leaves of these four Carex species all show quite different $C_{\text {max }}$, while the roots are dominated by $\mathrm{C}_{31}$ or $\mathrm{C}_{33}$ homologue. Leaves of $C$. bigelowii (Ficken et al., 1998) also showed a $C_{\max }$ at $\mathrm{C}_{27}$, similar to $C$. argyi in this study. The four Cyperaceae species analyzed by Nott et al. (2000) were all dominated by $\mathrm{C}_{31} n$-alkane. Variability in the $n$-alkane compositions within several species of one genus is common and has been described for other peatland plants, such as Sphagnum species (Baas et al., 2000).

\section{n-Alkanols}

All the samples contain $n$-alkanols in a range of $\mathrm{C}_{16}$ to $\mathrm{C}_{32}$ with an obvious even/odd predominance (Figs. 3 and 4$)$. The long chain homologues $\left(\mathrm{C}_{22}-\mathrm{C}_{32}\right)$ show a predominance over the short chain homologues $\left(<\mathrm{C}_{22}\right.$; Fig.

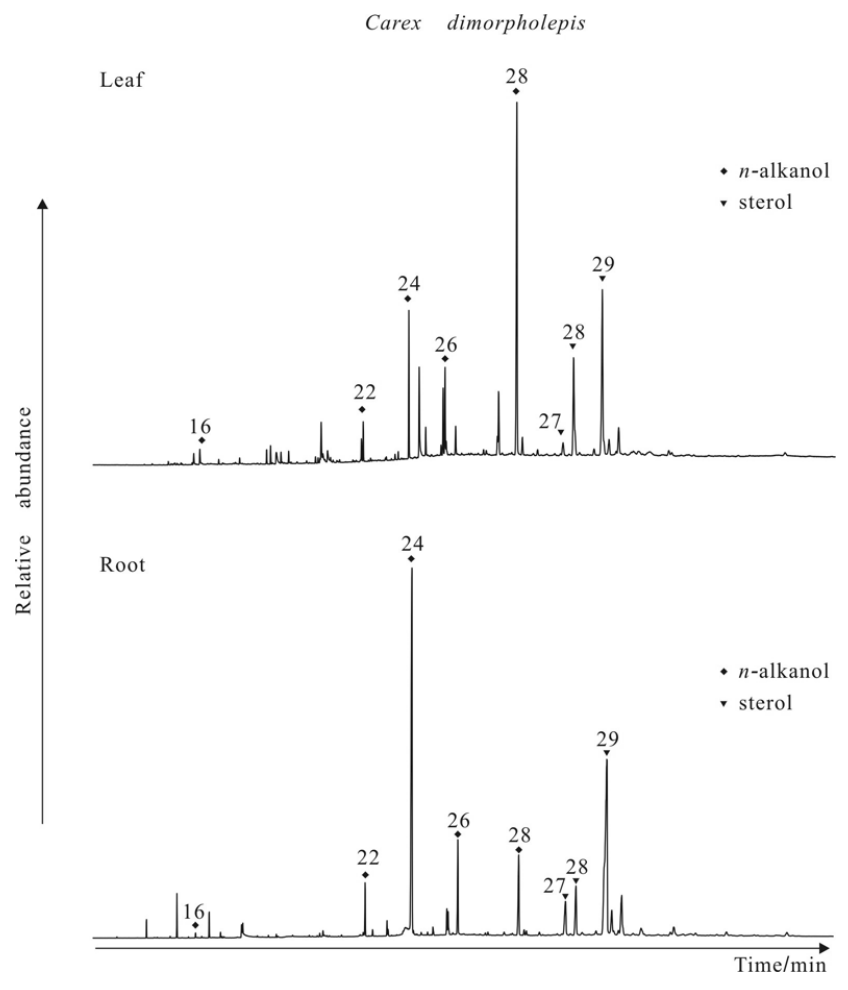

Fig. 3. The total ion chromatograph (TIC) of polar fraction of Carex dimorpholepis.

4), which is typical for higher plants (e.g., Kolattukudy et al., 1976). In all species, the roots normally contain shorter chain $n$-alkanols relative to the leaves (Fig. 4).

In seven of the twelve species, the leaves contain greater amounts of $n$-alkanols than the roots (Table 2). In contrast, $n$-alkanols are significantly enriched in the roots for two Carex species ( $C$. dimorpholepis and $C$. rochebruni; Table 2). A similar enrichment in roots vs. leaves has also been shown for E. tetralix (Pancost et al., 2002).

The $C_{\max }$ of $n$-alkanols varies in both roots and leaves (Fig. 4). For example, the leaves of the four Carex species show the $C_{\max }$ at $\mathrm{C}_{30}, \mathrm{C}_{28}$ and $\mathrm{C}_{24} n$-alkanols, while in the roots it is at $\mathrm{C}_{30}, \mathrm{C}_{28}$ and $\mathrm{C}_{26} n$-alkanols. The $n$ alkanol distribution of $C$. bigelowii given in Ficken et al. (1998) was dominated by $\mathrm{C}_{30}$ homologue. Plants other than mosses from peatlands normally have $C_{\max }$ at $\mathrm{C}_{28}$ or $\mathrm{C}_{30}$ homologue (Ficken et al., 1998; Pancost et al., 2002).

\section{Steroids}

Sterols are obvious in the polar fractions (Fig. 3). In all species, $\mathrm{C}_{29}$ sterols (24-ethylcholest-5-en-3 $\beta$-ol and 24 -ethylcholesta-5,22-dien-3 $\beta$-ol) dominate over $\mathrm{C}_{28}$ sterols. The dominant $\mathrm{C}_{27}$ sterol is cholest-5-en-3 $\beta$-ol, present at quite low amounts.

Sterols are selectively enriched in the roots of all the 

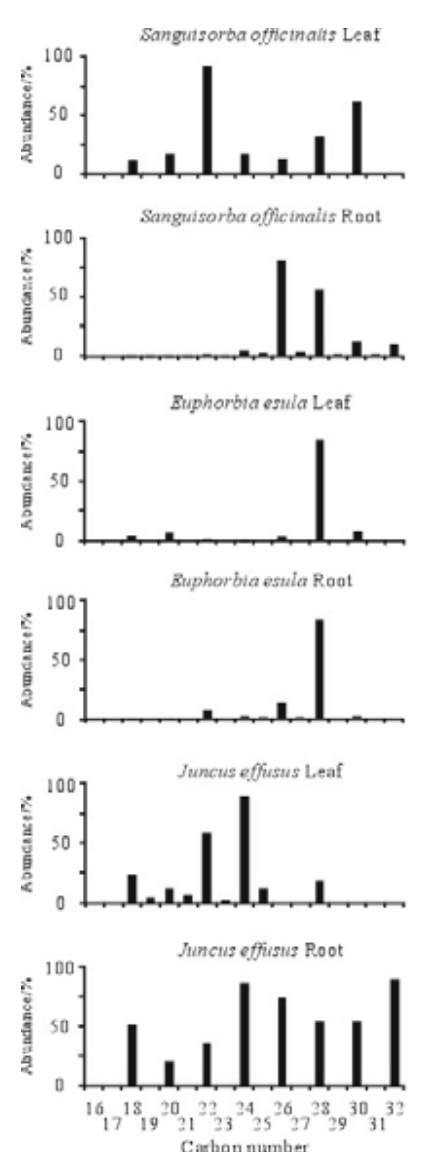
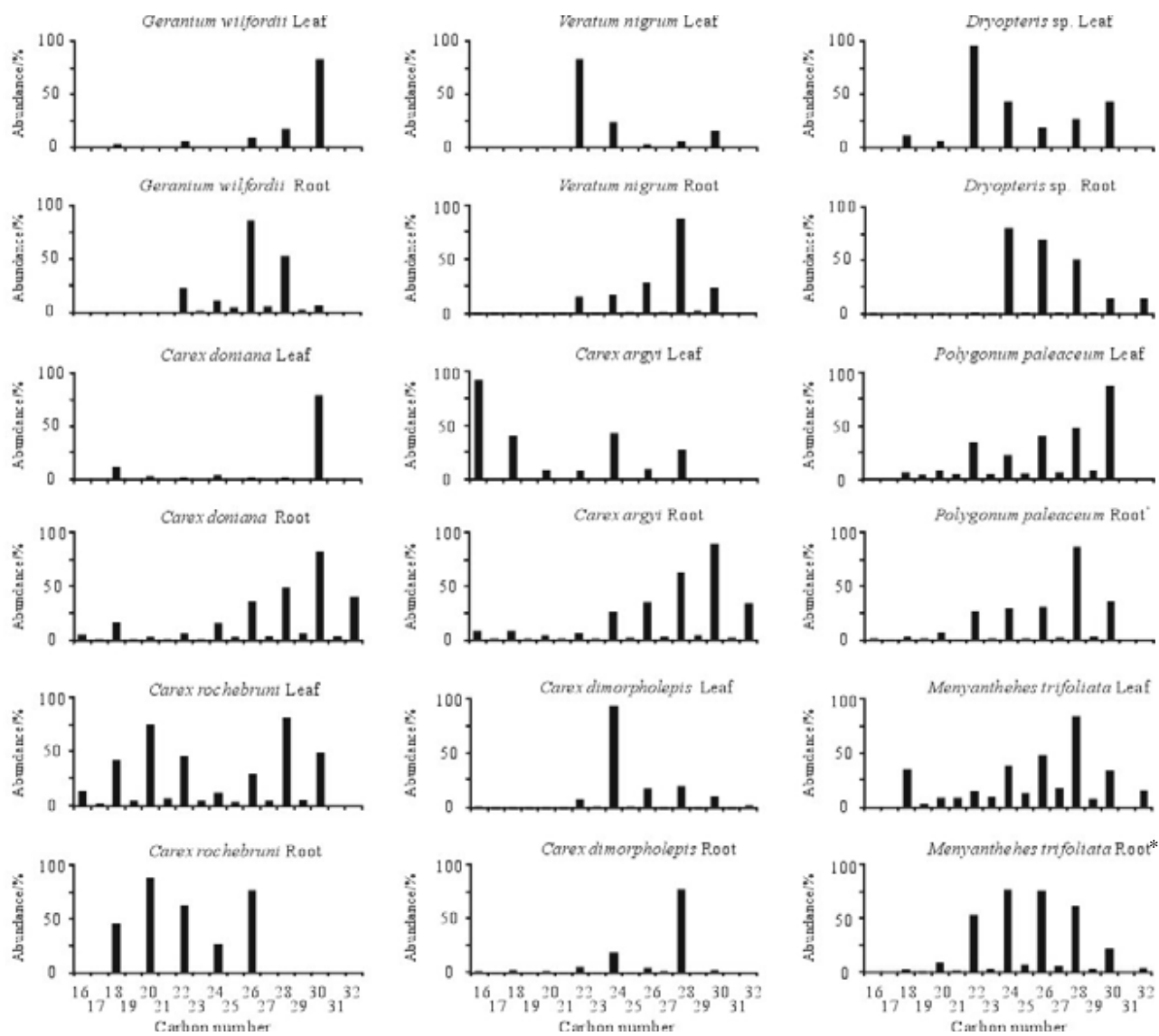

Fig. 4. Histograms showing the distributions of $n$-alkanols in the roots and leaves of plants from Dajiuhu Peatland $\left(C_{16}-C_{32}\right.$; * refers that the root of Menyantehes trifoliata is actually the mixture of roots and rhizome).

species (Table 2). This pattern is especially obvious for $J$. effusus and C. rochebruni, in which the amount of sterols in the roots is two orders of magnitude higher than that in the leaves (Table 2). A similar enrichment of sterols in roots relative to stems was also described for $E$. tetralix (Pancost et al., 2002). In the study of Dutch coastal dune soils, the oak roots were found to be comprised largely of triterpenoids and steroids (Nierop et al., 2005).

Two steroidal ketone compounds, stigmasta-3,5-dien7-one and stigmast-4-en-3-one, occur in the roots of all species (Fig. 5). Steroidal ketones are presumably intermediates in the oxidation of sterols to stanols (Wakeham, 1987), which has been demonstrated to occur through microbial oxidation by radiolabelling experiments (Gagosian et al., 1982). Thus, the occurrence of steroidal ketones in the roots of peatland plants probably results from microbial activity around the root systems.

\section{Implications for root derived lipids in peat deposits}

This study shows that plant roots can contribute relatively high amounts of free lipids to peatlands. In gen- eral, long chain $n$-alkanes and $n$-alkanols are more abundant in leaves than in roots, but in some species they show the enrichment in roots (e.g., $C$. dimorpholepis; Table 2). A significant contribution from root-derived lipids is confirmed by the steroids (sterols and steroidal ketones; Table 2), which predominantly occur in the roots of all the species. In addition, roots can contribute more short chain $n$-alkyl compounds to peat (e.g., $n$-alkanols) relative to their leaf counterparts.

These preliminary results reveal that more attention should be paid to root-derived lipids when interpreting the sources of lipids in soil and peat samples. This idea is probably more suitable for environments such as peatlands and wetlands, where plants are characterized by welldeveloped rootlets and shallow root systems that are acclimatized to the waterlogged conditions (Rydin and Jeglum, 2006). The importance of root-derived lipids has been postulated in the study of the Upper Oligocene Thierbach strata, Germany (Otto et al., 1994). The study of an experimental grassland soil also suggested that the root material was the predominant source of aliphatic acids in the soil of temperate grassland biomes (Bull et 


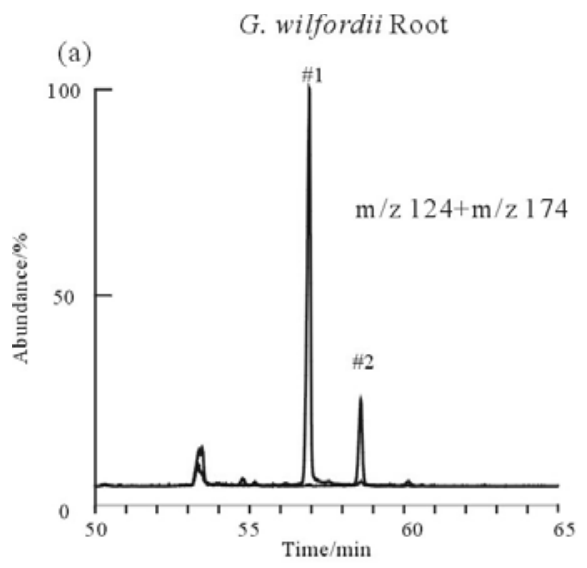

(c)

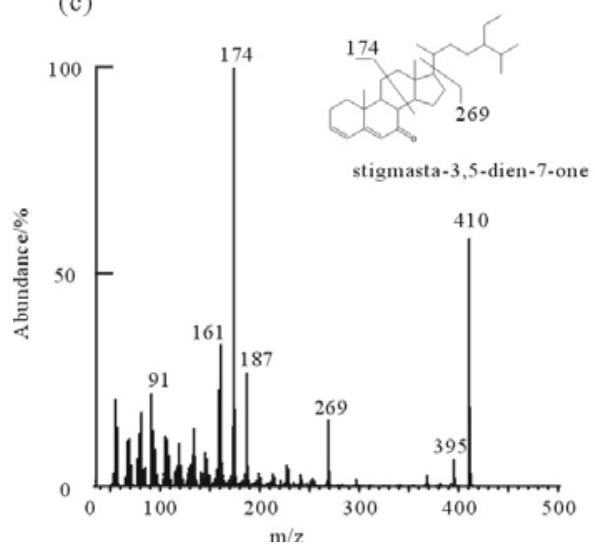

(b)

G. wilfordii Leaf

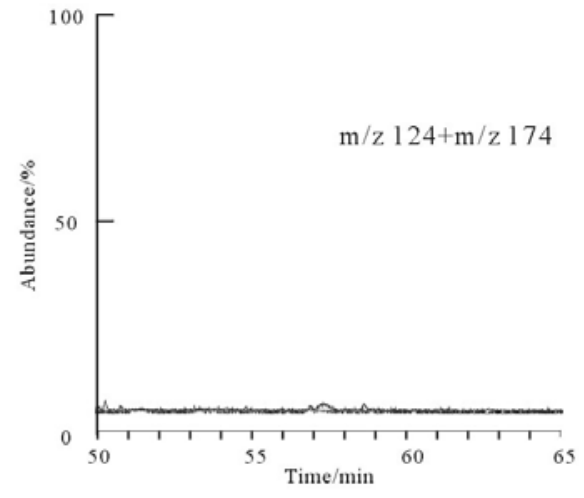

(d)

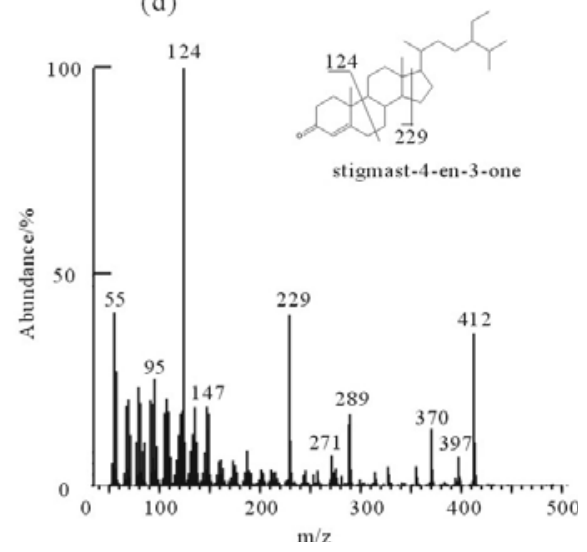

Fig. 5. Steroidal ketones in roots (a) and leaves (b) of G. wilfordii from Dajiuhu Peatland (\#1 and \#2 in (a) refer to stigmasta-3,5dien-7-one and stigmast-4-en-3-one, respectively). (c) and (d), mass spectra of stigmasta-3,5-dien-7-one and stigmast-4-en-3one, respectively.

al., 2000). Since this work only focuses on free plant lipids, it is better to further consider the contribution of bound lipids especially wax esters to evaluate the importance of bound lipids. Previous studies have shown that bound lipids can also contribute great amount of fatty acids, alkanols and sterols in sediments (Cranwell and Volkman, 1981; Disnar et al., 2005).

Half of the Dajiuhu plant species show a larger $n$-alkane $C_{\max }$ in the roots than in the leaves (Table 1 ). In leaf cuticles, main physiological function of long chain $n$-alkanes is thought to reduce the loss of water (e.g., Eglinton and Hamilton, 1967; Hauke and Scheriber, 1998; Jetter et al., 2006). It was found that plants growing in arid conditions synthesized greater proportions of longer chain homologues relative to their counterparts in humid conditions (Dodd et al., 1999). On the other hand, in peatlands, the surficial peat layers where the plant roots grow are typically wet, so that roots are unlikely to synthesize longer chain $n$-alkanes to reduce water loss. A more reasonable interpretation is that roots synthesize longer chain $n$-alkanes to compensate for the higher wa- ter osmotic pressure in the peatland. The longer $C_{\max }$ in roots vs. leaves also argues against the degradation theory recently proposed by authors for terrestrial soil-paleosol sequences (Buggle et al., 2010; Zech et al., 2010). These authors observed that, in deeper parts of paleosoils as well as recent soils, the ACL, $C_{\max }$ and CPI values decreased, and they attributed the effect exclusively to degradation. Our results indicate that the contribution of root-derived lipids can also result in similar modifications in molecular parameters. Therefore, especially in well rooted soils and sediments, the degradation effects on root-derived organic components have to be taken into account, rather than just above ground plant tissue.

The comparison between roots and leaves shows that the relative concentrations of short chain $n$-alkanols $\left(<\mathrm{C}_{22}\right)$ and steroidal ketones are generally enriched in roots (Figs. 4 and 5). Short chain $n$-alkanols are thought to be biomarkers for microbes (Volkman et al., 1999; Xie et al., 2003), while the origins of steroidal ketones are attributed to microbial oxidation of sterols (Wakeham, 1987). In this study, the relative enrichment of short chain 
$n$-alkanols $\left(<\mathrm{C}_{22}\right)$ and steroidal ketones in roots may be associated with microorganisms in and around the root systems, which cannot be completely separated from roots. Therefore, the potential contributions of rhizomicrobial remains have to be considered when analyzing root tissues for their lipid composition (Wiesenberg et al., 2004, 2010).

\section{Conclusions}

Analysis of the free lipid compositions of the roots and leaves of plant species collected from the Dajiuhu Peatland reveals that roots may be important sources of lipid biomarkers in peats and especially of sterols and steroidal ketones. In some cases, roots can contribute more long chain $n$-alkanes and $n$-alkanols than their leaf counterparts. By considering both leaf- and root-derived free and bound lipids, we can better understand organic matter production, preservation, and the associated carbon cycle in soils and terrestrial sedimentary environments like peatlands, which are important terrestrial carbon sinks.

Acknowledgments - The work was supported by the 973 project (Grant No. 2011CB808800), NSFC (Grant Nos. 40930210, 40921062), MOST Special Fund from the State Key Laboratory of Geological Processes and Mineral Resources (MSFGPMR200910), the Special Fund for Basic Scientific Research of Central Colleges, China University of Geosciences (CUG090103), and the 111 project (B08030). Yanming Qin and Ze Zhang provided help during field trips. Weichao $\mathrm{Wu}$ and Jiantao Xue are acknowledged for sample treatments. Prof. JeanRobert Disnar, Dr. Rina Argelia Garcia and the associate editor Dr. Ken Sawada are thanked for constructive comments. Prof. Philp A. Meyers from Michigan University kindly helped to improve the English writing of the revised manuscript.

\section{REFERENCES}

Baas, M., Pancost, R., van Geel, B. and Sinninghe Damsté, J. S. (2000) A comparative study of lipids in Sphagnum species. Org. Geochem. 31, 535-541.

Bi, X., Sheng, G., Liu, X., Li, C. and Fu, J. (2005) Molecular and carbon and hydrogen isotopic composition of $n$-alkanes in plant leaf waxes. Org. Geochem. 36, 1405-1417.

Bingham, E. M., McClymont, E. L., Väliranta, M., Mauquoy, D., Roberts, Z., Chambers, F. M., Pancost, R. D. and Evershed, R. P. (2010) Conservative composition of $n$-alkane biomarkers in Sphagnum species: Implications for palaeoclimate reconstruction in ombrotrophic peat bogs. Org. Geochem. 41, 214-220.

Buggle, B., Wiesenberg, G. L. B. and Glaser, B. (2010) Is there a possibility to correct fossil $n$-alkane data for post sedimentary alteration effects? Appl. Geochem. 25, 947-957.

Bull, I. D., Nott, C. J., van Bergen, P. F., Poulton, P. R. and Evershed, R. P. (2000) Organic geochemical studies of soils from the Rothamsted classical experiments-VI. The oc- currence and source of organic acids in an experimental grassland soil. Soil Biol. Biochem. 32, 1367-1376.

Cranwell, P. A. and Volkman, J. K. (1981) Alkyl and steryl esters in a recent lacustrine sediment. Chem. Geol. 32, 2943.

Cui, J., Huang, J. and Xie, S. (2008) Characteristics of seasonal variations of leaf $n$-alkanes and $n$-alkenes in modern higher plants in Qingjiang, Hubei Province, China. Chin. Sci. Bull. 53, 2659-2664.

Disnar, J. R., Stefanova, M., Bourdon, S. and Laggoun-Défarge, E. (2005) Sequential fatty acid analysis of a peat core covering the last two millennia (Tritrivakely lake, Madagascar): diagenesis appraisal and consequences for palaeoenvironmental reconstruction. Org. Geochem. 36, 1391-1404.

Djerassi, C. (1978) Recent advances in the mass spectrometry of steroids. Pure Appl. Chem. 50, 171-184.

Dodd, R. S., Blasco, F., Rafii, Z. A. and Torquebiau, E. (1999) Mangroves of the United Arab Emirates: ecotypic diversity in cuticular waxes at the bioclimatic extreme. Aquat. Bot. 63, 291-304.

Duan, Y. and Ma, L. (2001) Lipid geochemistry in a sediment core from Ruoergai Marsh deposit Eastern Qinghai-Tibet plateau, China. Org. Geochem. 32, 1429-1442.

Eglinton, G. and Hamilton, R. J. (1967) Leaf epicuticular waxes. Science 156, 1322-1335.

Ficken, K. J., Barber, K. E. and Eglinton, G. (1998) Lipid biomarker, $\delta^{13} \mathrm{C}$ and plant macrofossil stratigraphy of a Scottish montane peat bog over the last two millennia. Org. Geochem. 28, 217-237.

Ficken, K. J., Li, B., Swain, D. L. and Eglinton, G. (2000) An $n$-alkane proxy for the sedimentary input of submerged/ floating freshwater aquatic macrophytes. Org. Geochem. 31, 745-749.

Gagosian, R. B., Smith, S. O. and Nigrelli, G. E. (1982) Vertical transport of steroid alcohols and ketones measured in a sediment trap experiment in the equatorial Atlantic Ocean. Geochim. Cosmochim. Acta 46, 1163-1172.

Grice, K., Lu, H., Zhou, Y., Stuart-Williams, H. and Farquhar, G. D. (2008) Biosynthetic and environmental effects on the stable carbon isotopic compositions of anteiso-(3-methyl) and iso-(2-methyl) alkanes in tobacco leaves. Phytochemistry 69, 2807-2814.

Hauke, V. and Scheriber, L. (1998) Ontogenetic and seasonal development of wax composition and cuticular transpiration of ivy (Hedera helix L.) sun and shade leaves. Planta 207, 67-75.

Huang, X. Y., Xie, S. C., Zhang, C. L., Jiao, D., Huang, J. H., Yu, J. X., Jin, F. and Gu, Y. S. (2008) Distribution of aliphatic des-A-triterpenoids in the Dajiuhu peat deposit, southern China. Org. Geochem. 39, 1765-1771.

Huang, X. Y., Wang, C. F., Xue, J. T., Meyers, P. A., Zhang, Z., Tan, K. J., Zhang, Z. Q. and Xie, S. C. (2010) Occurrence of diploptene in moss species from the Dajiuhu Peatland in southern China. Org. Geochem. 41, 321-324.

Huang, X. Y., Meyers, P. A., Wu, W. C., Jia, C. L. and Xie, S. C. (2011) Significance of long chain iso and anteiso monomethyl alkanes in the Lamiaceae (mint family). Org. Geochem. 42, 156-165. 
Jansen, B., Nierop, K. G. J., Hageman, J. A., Cleef, A. M. and Verstraten, J. M. (2006) The straight-chain lipid biomarker composition of plant species responsible for the dominant biomass production along two altitudinal transects in the Ecuadorian Andes. Org. Geochem. 37, 1514-1536.

Jetter, R., Kunst, L. and Samuels, A. L. (2006) Composition of plant cuticular waxes. Biology of the Plant Cuticle (Riedrer, M. and Müller, C., eds.), 145-181, Blackwell Publishing Ltd.

Kolattukudy, P. E., Croteaa, R. and Buckner, J. S. (1976). Biochemistry of plant waxes. Chemistry and Biochemistry of Natural Waxes (Kolattukudy, P. E., ed.), 290-348, Elsevier.

Kuhn, T. K., Krull, E. S., Bowater, A., Grice, L. and Gleixner, G. (2010) The occurrence of short-chain $n$-alkanes with an even over odd predominance in higher plants and soils. Org. Geochem. 41, 88-95.

Mendez-Millan, M., Dignac, M. F., Rumpel, C., Rasse, D. P. and Derenne, S. (2010) Molecular dynamics of shoot vs. root biomarkers in an agricultural soil estimated by natural abundance ${ }^{13} \mathrm{C}$ labeling. Soil Biol. Biochem. 42, 169-177.

Meyers, P. A. and Ishiwatari, R. (1993) Lacustrine organic geochemistry - an overview of indicators of organic matter sources and diagenesis in lake sediments. Org. Geochem. 20, 867-900.

Nichols, J. E., Booth, R. K., Jackson, S. T., Pendall, E. G. and Huang, Y. (2006) Paleohydrologic reconstruction based on $n$-alkane distributions in ombrotrophic peat. Org. Geochem. 37, 1505-1513.

Nierop, K. G. J., Naafs, D. F. W. and van Bergen, P. F. (2005) Origin, occurrence and fate of extractable lipids in Dutch coastal dune soils along a pH gradient. Org. Geochem. 36, $555-566$.

Nott, C. J., Xie, S. C., Avsejs, L. A., Maddy, D., Chambers, F. M. and Evershed, R. P. (2000) n-Alkane distributions in ombrotrophic mires as indicators of vegetation change related to climatic variation. Org. Geochem. 31, 231-235.

Otto, A., Walther, H. and Püttmann, W. (1994) Molecular composition of a leaf- and root-bearing Oligocene Oxbow Lake Clay in the Weisselster Basin, Germany. Org. Geochem. 22, 275-286.

Pancost, R. D., Baas, M., van Geel, B. and Sinninghe Damsté, J. S. (2002) Biomarkers as proxies for plant inputs to peats: an example from a sub-boreal ombrotrophic bog. Org. Geochem. 33, 675-690.

Rieley, G., Collier, R. J., Jones, D. M. and Eglinton, G. (1991) The biogeochemistry of Ellesmere Lake, U.K.-1: source correlation of leaf wax inputs to the sedimentary lipid record. Org. Geochem. 17, 901-912.
Rommerskirchen, F., Plader, A., Eglinton, G., Chikaraishi, Y. and Rüllkotter, J. (2006) Chemotaxonomic significance of distribution and stable carbon isotopic composition of longchain alkanes and alkan-1-ols in $\mathrm{C}_{4}$ grass waxes. Org. Geochem. 37, 1303-1332.

Rydin, H. and Jeglum, J. K. (2006) The Biology of Peatlands. Oxford Univ. Press Inc.

Schwark, L., Zink, K. and Lechterbeck, J. (2002) Reconstruction of postglacial to early Holocene vegetation history in terrestrial Central Europe via cuticular lipid biomarkers and pollen records from lake sediments. Geology 30, 463-466.

Volkman, J. K., Barrett, S. M. and Blackburn, S. I. (1999) Eustigmatophyte microalgae are potential sources of $\mathrm{C}_{29}$ sterols, $n-\mathrm{C}_{23}-n-\mathrm{C}_{28} n$-alkanols and $\mathrm{C}_{28}-\mathrm{C}_{32} n$-alkyl diols in freshwater environments. Org. Geochem. 30, 307-318.

Vonk, J. E. and Gustafsson, Ö. (2009) Calibrating n-alkane Sphagnum proxies in sub-Arctic Scandinavia. Org. Geochem. 40, 1085-1090.

Wakeham, S. G. (1987) Steroid geochemistry in the oxygen minimum zone of the eastern tropical North Pacific Ocean. Geochim. Cosmochim. Acta 51, 3051-3069.

Wiesenberg, G. L. B. and Schwark, L. (2006) Carboxylic acid distribution patterns of temperate $\mathrm{C}_{3}$ and $\mathrm{C}_{4}$ crops. Org. Geochem. 37, 1973-1982.

Wiesenberg, G. L. B ., Schwarzbauer, J., Schmidt, M. W. I. and Schwark, L. (2004) Source and turnover of organic matter in agricultural soils derived from $n$-alkane $/ n$-carboxylic acid compositions and C-isotope signatures. Org. Geochem. 35 , 1371-1393.

Wiesenberg, G. L. B., Gocke, M. and Kuzyakov, Y. (2010) Fast incorporation of root-derived lipids and fatty acids into soil-evidence from a short term multiple ${ }^{14} \mathrm{CO}_{2}$ pulse labeling experiment. Org. Geochem. 41, 1049-1055.

Xie, S. C., Yi, Y., Huang, J. H., Hu, C. Y., Collins, M. and Baker, A. (2003) Lipid distribution in a subtropical southern China stalagmite as a record of soil ecosystem response to paleoclimate change. Quat. Res. 60, 340-347.

Xie, S. C., Nott, C. J., Avsejs, L. A., Maddy, D., Chambers, F. M. and Evershed, R. P. (2004) Molecular and isotopic stratigraphy in an ombrotrophic mire for paleoclimate reconstruction. Geochim. Cosmochim. Acta 68, 2849-2862.

Zech, M., Buggle, B., Leiber, K., Markovic, S., Glaser, B., Hambach, U., Huwe, B., Stevens, T., Sümegi, P., Wiesenberg, G. and Zöller, L. (2010) Reconstructing Quaternary vegetation history in the Carpathian Basin, SE Europe, using $n$-alkane biomarkers as molecular fossils: problems and possible solutions, potential and limitations. $E$ \& G - Quarternary Science Journal 58, 148-155. 